\title{
A necessary discussion on consumer vulnerability: advances, gaps, and new perspectives
}

\author{
ROSANA OLIVEIRA DA SILVA ${ }^{1}$ \\ DENISE FRANCA BARROS ${ }^{1}$ \\ TÂNIA MARIA de OliveIRA Almeida Gouveia ${ }^{2}$ \\ Daniel de Oliveira Barata Merabet ${ }^{1}$
}

\author{
${ }^{1}$ UNIVERSIDADE DO GRANDE RIO (UNIGRANRIO), RIO DE JANEIRO - RJ, BRAZIL \\ 2 UNIVERSIDADE DO ESTADO DO RIO DE JANEIRO (UERJ), RIO DE JANEIRO - RJ, BRAZIL
}

\begin{abstract}
Consumer research is not usually concerned with problems caused or aggravated by market activities. However, economic, social, environmental, and public health problems can be attributed to certain market practices, which are harmful to different market agents. This article examines how consumer vulnerability has been discussed in the marketing and consumer literature through a national and international literature review of the last 25 years. It seeks to identify the different perspectives and definitions in researches that discuss the topic and suggests a comprehensive definition of vulnerability in the marketing area, which considers the vulnerability of other agents. We identified vulnerability as an issue gaining importance, despite the predominance of a managerialist perspective, which emphasizes the generation of knowledge that benefits companies. It seems urgent that marketing and consumer studies are interested in knowledge that protects and benefits consumers and society in general. We believe that the study of vulnerability should also encourage the development of adequate public policies and the discussion of regulatory activities, in addition to the consumer. Thus, from the results, we suggest that vulnerability can be defined as a state of individuals' fragility in the face of market practices, which can manifest in different stages in production, commercialization, and consumption processes.
\end{abstract}

Keywords: Consumer vulnerability. Market systems. Consumer studies. Public policy. Macromarketing.

\section{Uma discussão necessária sobre a vulnerabilidade do consumidor: avanços, lacunas e novas perspectivas}

\section{Resumo}

A pesquisa sobre o consumidor não se ocupa comumente dos problemas causados e/ou agravados pelas atividades de mercado. Entretanto, problemas econômicos, sociais, ambientais e de saúde pública podem ser atribuídos a determinadas práticas de mercado, nocivas a distintos agentes que nele atuam. Assim, este artigo tem o objetivo de examinar como o conceito de vulnerabilidade do consumidor vem sendo discutido na literatura de marketing e de consumo, por meio de uma revisão da literatura dos últimos 25 anos na produção nacional e internacional de congressos científicos e periódicos. Procura-se identificar as diferentes perspectivas e definições nas principais fontes em que a temática é discutida, com o objetivo de sugerir uma definição abrangente para a vulnerabilidade na área de marketing e que leva em conta a vulnerabilidade de outros agentes. Identificamos que a vulnerabilidade é um tema que vem adquirindo importância, apesar da predominância de uma perspectiva gerencialista, que prioriza a geração de conhecimento benéfico às empresas. Parece-nos urgente que Marketing e Estudos de Consumo interessem-se por conhecimento que proteja e beneficie o consumidor e a sociedade em geral. Acreditamos que o estudo da vulnerabilidade também deve suscitar o desenvolvimento de políticas públicas adequadas e a discussão sobre as atividades reguladoras, para além do consumidor. Assim, com base nos resultados, sugerimos que a vulnerabilidade pode ser definida como um estado de fragilidade de indivíduos frente às práticas de mercado e que pode manifestar-se em diferentes etapas no processo de produção, comercialização e consumo.

Palavras-chave: Vulnerabilidade do consumidor. Sistemas de marketing. Estudos de consumo. Políticas públicas. Macromarketing.

\section{“Una discusión necesaria sobre la vulnerabilidad del consumidor: avances, brechas y nuevas perspectivas}

\section{Resumen}

La investigación sobre el consumidor no se ocupa comúnmente de los problemas causados y/o agravados por las actividades del mercado. Sin embargo, hay problemas económicos, sociales, ambientales y de salud pública que pueden atribuirse a ciertas prácticas de mercado, perjudiciales para los diferentes agentes que operan en él. Por lo tanto, este artículo tiene como objetivo examinar cómo se ha discutido el concepto de vulnerabilidad del consumidor en la literatura de marketing y consumo, a través de una revisión de la literatura de los últimos 25 años en la producción nacional e internacional de congresos científicos y periódicos. Busca identificar las diferentes perspectivas y definiciones, en las principales fuentes en las que se discute el tema, para sugerir una definición integral de vulnerabilidad en el área de marketing, que considera la vulnerabilidad de otros agentes. Identificamos que la vulnerabilidad es un tema que ha ido ganando importancia, a pesar del predominio de una perspectiva gerencial, que prioriza la generación de conocimiento que beneficia a las empresas. Parece urgente que los estudios de marketing y consumo se interesen en un conocimiento que proteja y beneficie al consumidor y a la sociedad en general. Consideramos que el estudio de la vulnerabilidad también debería alentar el desarrollo de políticas públicas adecuadas y la discusión de actividades reguladoras, más allá del consumidor. Por lo tanto, a partir de los resultados, sugerimos que la vulnerabilidad se puede definir como un estado de fragilidad de los individuos frente a las prácticas de mercado, que puede manifestarse en diferentes etapas en el proceso de producción, comercialización y consumo.

Palabras clave: Vulnerabilidad del consumidor. Sistemas de marketing. Estudios de consumo. Políticas públicas. Macromarketing. 


\section{INTRODUCTION}

Consumer research is not usually concerned with the problems caused and/or aggravated by market activities (Sauerbronn, 2013; Shultz II \& Holbrook, 2009), but economic, social, environmental or public health problems can be attributed to certain market practices. The practices of production, commercialization and consumption of products and services which can generate employment, economic development, and well-being, among other positive results, can also produce direct and/or indirect negative results, whose extent is not limited to consumers, and can affect distinct market agents and society in general (Nason, 1989; Shultz II \& Holbrook, 2009).

Marketing professionals are, in turn, sometimes accused of exploiting consumers, especially those who are in a vulnerable position (Hackley, 2009; Shultz II \& Holbrook, 2009). Smith and Cooper-Martin (1997) and Karpatkin (1999) point out that various companies benefit from anti-ethical segmentation practices, with the objective being the markets of populations that are known to be vulnerable, selling products known to be harmful such as tobacco, alcohol, fast food, creating and/ or reinforcing addictive behavior and health problems. In addition, the consequences of marketing activities and/or the consumption of products can affect populations in different ways, which suggests the existence of individuals and groups which can be more vulnerable to given problems and/or industry actions (Commuri \& Ekici, 2008).

Besides the anti-ethical behavior that companies and/or marketing professionals can assume in creating, promoting and commercializing their products and services, and therefore, harming their consumers, the marketing and consumption literature should be concerned with problems which are consequences of everyday marketing activities. Nason (1989) points out that the production and consumption of products and services can cause harmful effects to individuals and organizations - even in an unintentional or unpremeditated way. Environmental problems created by the disposal of substances used in production processes, diseases caused by the handling of pesticides, and stigmas suffered by the families of alcoholics are some of the examples of vicissitudes that can affect workers, industry suppliers, consumers, and society in general. Given these and other problems, there is a need to involve regulatory entities and develop public policies.

To the extent that these consequences of market activities accumulate, they generate aggregate (in)direct complications that are capable of influencing public health (such as diseases associated with tobacco which overload public hospital budgets), worker health (such as those exposed to pesticides) and the environment, where damage can be potentially greater, since it includes the previous items.

It is possible to observe that in all of these examples there exists some degree of vulnerability - this may be limited to the consumer or may affect various agents. However, the problems due to marketing activities are not usually attributed to the discipline and/or practice of marketing. This may be the reason why vulnerability in marketing is restricted to the consumer, given terms such as "vulnerable consumers" and "consumer vulnerability". Normally problems due to market activities are seen as a management error and not as part of the marketing structure itself. We argue here that in not recognizing these problems (at least in part) as a consequence of production, commercialization and consumption activities, academia and marketing practitioners are neglecting important aspects of its scope and relationship with society.

The relationships between the market, marketing practices, and society were an important subject in the initial moments of the marketing discipline (Boschi, Barros \& Sauerbronn, 2016; Nason, 2011; Shapiro, Tadajewski \& Shultz II, 2009; Wilkie \& Moore, 2003). It sought to answer in what manner marketing practices could generate benefits and/or problems for society and whether this behavior should or should not be regulated (Nason, 2011; Wilkie \& Moore, 2003). This perspective lost relevance with the emergence of the marketing managerialist paradigm at the end of the 1960s (Hunt, 1976; Layton \& Grossbart, 2006), which was a more restricted concept, characterized by an emphasis on its profit, micro- and normative dimensions (Hunt, 1976).

In Brazil, the concept of consumer vulnerability (henceforth CV) originally gained importance in terms of the law. For this reason, in the 1970s people began to speak of protecting consumers (Bitencourt, 2004). Even though in the 1960 s there was already discussion in the marketing area of the asymmetry between large companies and consumers (Hemais \& Faria, 2012), the same did not occur in Brazil. CV only received attention in this county during the 1990s (Baker, Gentry \& Rittenburg, 2005). 
However, social issues are ignored by the large majority of marketing researchers (Sheth \& Sisodia, 2005). Marginalizing subjects such as regulation and the consequences of marketing activities can compromise consumer and societal well-being, especially if one ignores their fragile situation.

We argue that this subject deserves greater attention and we intend to contribute to a call to action to provide an overall view that summarizes and analyzes production in relation to a subject that has been treated in a manner that is recognized as being fragmented (Pavia \& Mason, 2014; Piacentini, Dunnett \& Hamilton, 2014), and which ignores the vulnerability of other agents. This being so, in this article we seek to examine how the concept of CV has been discussed in the marketing and consumption literature through a review of the national and international literature of the past 25 years, identifying the different perspectives and definitions of the main sources in which this subject is discussed, seeking to suggest a broad definition for vulnerability in the marketing area, which also considers the vulnerability of other agents present in the system.

\section{Consumer Vulnerability: Initial Considerations}

Vulnerability suggests an unfavorable condition, some level of fragility that exposes the individual to potential danger, placing him or her in an inferior position. In law, the concept of being vulnerable is particularly important so that equal rights can be guaranteed to every and any individual who needs special protection (Oliveira, 2010).

The preoccupation with the protection of consumer relationships, which are complex and conflicting, arose in law at the end of the $19^{\text {th }}$ century at the time of the appearance of the production line, which later led to the creation of organizations which were designed to protect consumers such as Consumer Protection and Defense (PROCON) and the Brazilian Institute for Consumer Defense (IDEC). The Consumer Defense Code, Law no 8,078 (1990) seeks to protect the consumer from vulnerable situations in their dealings with companies.

Bitencourt (2004) argues that all consumers are vulnerable in their relationships with the suppliers of goods and services, being at the mercy of those with company control. The need for protection can be even greater for low income consumers who also have to deal with discrimination (Santo \& Hemais, 2017). Ferrari and Takey (2014, p. 6) explain that "[...] legal vulnerability emanates from difficulties that consumers encounter in defending their rights in dealing with suppliers, given that this imposes many difficulties." From a legal perspective, vulnerability is related to "[...] the weak side of a subject or issue [individuals or companies] [...]" and "[...] a point where someone can be attacked or offended [temporarily or permanently]" (Lima, 2011, p. 245), with no relationship to socioeconomic and cultural characteristics.

Even though the first work about CV in 1963 was the book The Poor Pay More: Consumer Practices of Low-Income Families, by David Caplovitz (Baker et al., 2005), it was only in the 1990s that there were advances in marketing and consumption research. These studies did not offer a clear definition, but replicated how courts defined CV (Baker et al., 2005): "[...] the concept of vulnerability is important because it involves consumer well-being, as well as the responses of companies, policies and society to the consumer's lack of well-being" (Baker, Geiger-Oneto \& Gentry, 2011, p. 176). What these studies have in common is the frequent relationship between vulnerability and disadvantage, even though not all those at disadvantage experience vulnerability, and people without disadvantages, even perceived ones, can also experience vulnerability (Baker et al., 2005).

The most cited article about this subject, defines CV as:

[...] a state of impotence which results from a disequilibrium in market interactions or the consumption of marketing and product messages. [...] it occurs when control is not in the hands of the individual, creating a dependency on external factors (merchants for example) to create equity in the market (Baker et al., 2005, p. 7).

In a complementary manner, to Visconti $(2016$, p. 371) it is "[...] a market condition which exposes one or more individuals to the risk of obtaining limited utility in market transactions, with implications for their well-being." CV can differ in terms of etiology (e.g., cultural, economic, social), duration (permanent or transitory), locus (market versus social life), significance (consumerist versus non-consumerist) and the number of people who share the condition of being vulnerable (individual or social). Therefore, the author broadens the concept of vulnerability and recognizes the existence of classes which are more susceptible to harm (e.g., immigrants, the homeless, gays) (Visconti, 2016, p. 372). 
Baker and Mason (2012) recognize the lack of broader studies about vulnerability, because the market and consumption can be simultaneously the source of conflicts, risks, vulnerability, significance and pleasure which affect various segments of the public. The special edition of the Journal of Macromarketing of 2005, emphasized gaps and the need for broader studies (Commuri \& Ekici, 2008) as well as the role of micromarketing academics in the understanding of CV (Rittenbourg \& Lunde, 2016). In this case, micromarketing is understood as the study of systemic relationships between marketing actors (Bagozzi, 1977) or as the study of the commercialization system and the mutual impacts and consequences between this system and society (Hunt \& Burnett, 1982), as well as a preoccupation with social well-being (Miranda \& Arruda, 2004). Transformative Consumer Research (TCR) is also an area in which CV is usually addressed, because this area is dedicated to "[...] the study and understanding of consumption behavior in terms of individual and collective well-being, offering society a positive response to the negligent impacts of marketing" (Pinto, Batinga, Ássimos \& Almeida, 2016, p. 54). Thus, the areas of micromarketing and TCR concentrate the majority of the incipient research about CV.

\section{METHODOLOGICAL PROCEDURES}

Like the classic article by Arnould and Thompson (2005) and the recent studies of Coda and Castro (2019), Demo, Fogaça and Costa (2018) and Kuzma, Doliveira and Silva (2017), we have reviewed the literature to identify how the concept of CV is treated. To Ferenhof and Fernandes (2016, p. 551), the review of the literature is "[...] the base for the identification of current scientific knowledge" and the "gaps to be explored in certain subjects" through a "[...] methodology [which] consists of a series of preestablished procedures" (Coda \& Castro, 2019, p. 260).

It is important to highlight that, since we are dealing with an emerging subject - even though it is not new - we have included conference papers, given that these events are designed to discuss evolving subjects. Thus, we analyzed the past 25 years of national scientific conferences (EMA, EnANPAD, SemeAd, AdCONT and ENEC) and journals (extracted from the indexers SCIELO Brasil and SPELL) and international conferences and journals (Annals of Macromarketing Conference, Journal of Macromarketing, Journal of Public Policy and Journal Public Policy \& Marketing, Journal of Business Ethics and Journal of Marketing). The selected conferences are specific or have marketing tracks, and are also longstanding events (from 8 to 44 years). The Macromarketing Conference has an exclusive space for articles about CV. We selected international journals in marketing, micromarketing, ethics and public policies (axes where vulnerability is or can be addressed) of notable relevance, due to their longevity and classification in the Qualis-Capes system as A1 and/or in the JCR index or $\mathrm{H}$-index. In terms of the national sources, we opted for the two indexers and articles classified by Capes as Qualis A2 and B2 (with the exception of the Revista Interdisciplinar de Marketing (Interdisciplinary Marketing Magazine), classified as B4). The classifications of the journals was verified using the Sucupira Platform (2018).

We used the keywords "vulnerability" and "vulnerable" for the research. Despite the large number of results (more than 1,500 articles), the initial reading of the abstracts revealed that the great majority were not about CV, which led us to discard these articles, as well as duplicates and/or those in other areas, leaving 29 national and 138 international sources.

We concentrated on the theoretical and empirical aspects, on the thematic analysis of the theoretical frameworks, objectives, conclusions and results, in a manner similar to the study performed by Coda and Castro (2019), and the critical evaluation of articles realized by Kuzma et al. (2017). Our thematic analysis revealed three large perspectives in respect to vulnerability as described in Box 1. 
Box 1

Perspectives about Vulnerability

\begin{tabular}{|c|c|c|c|}
\hline Perspectives & $\begin{array}{l}\text { Factors which Cause } \\
\text { Vulnerability }\end{array}$ & $\begin{array}{l}\text { Examples or } \\
\text { Explanations }\end{array}$ & Example \\
\hline \multirow{3}{*}{$\begin{array}{l}\text { Conditions which } \\
\text { lead to } \\
\text { vulnerability }\end{array}$} & $\begin{array}{c}\text { Individual } \\
\text { characteristics }\end{array}$ & $\begin{array}{l}\text { Poor, children, ethnic minorities, immigrants, } \\
\text { women, elderly, handicapped people. }\end{array}$ & \multirow{3}{*}{$\begin{array}{l}\text { Baker et al. } \\
\text { (2005) }\end{array}$} \\
\hline & Transitory state & Marriage, divorce and death. & \\
\hline & External factors & $\begin{array}{l}\text { Stigmatization, discrimination, } \\
\text { physical and logistic elements. }\end{array}$ & \\
\hline $\begin{array}{l}\text { Ethical } \\
\text { issues }\end{array}$ & $\begin{array}{l}\text { Marketing strategies } \\
\text { can influence } \\
\text { vulnerability }\end{array}$ & $\begin{array}{l}\text { Segmentation of the vulnerable population, } \\
\text { sale of harmful products and the } \\
\text { moral responsibility of marketing. }\end{array}$ & $\begin{array}{l}\text { Smith and } \\
\text { Cooper-Martin } \\
(1997)\end{array}$ \\
\hline $\begin{array}{l}\text { CV as a result } \\
\text { of marketing } \\
\text { systems }\end{array}$ & $\begin{array}{l}\text { Market activities can } \\
\text { generate negative } \\
\text { consequences }\end{array}$ & $\begin{array}{l}\text { Production, commercialization and consumption } \\
\text { practices of products and services can } \\
\text { produce direct and/or indirect negative results } \\
\text { on consumers and/or society in general. }\end{array}$ & $\begin{array}{l}\text { Nason (1989); } \\
\text { Shultz II and } \\
\text { Holbrook (2009) }\end{array}$ \\
\hline
\end{tabular}

Source: Elaborated by the authors.

It is important to emphasize that the perspectives are different from each other, but may be present simultaneously in some works. For this reason, some studies appear in more than one of the above cited perspectives. In this manner, we observe that $\mathrm{CV}$ is treated in the literature from various perspectives, but they possess a certain complementarity among themselves.

\section{ANALYSIS OF THE RESULTS}

\section{Conditions which lead to vulnerability}

This perspective refers to the group of articles that discusses vulnerability in terms of its antecedents, in order to create useful definitions to understand how to treat it. The permanent or transitory nature of vulnerability is important in this category.

Vulnerability is commonly seen as a transitory condition, as something which can occur in difficult moments (mourning, divorce...) (Commuri \& Ekici, 2008), natural disasters (e.g., BAKER, 2009) or in the difficulty to make decisions at the time of purchase (especially for the handicapped, homeless...) (e.g., Pechmann et al., 2011). There are also permanent states, such as difficulties in comprehension (e.g., Viswanathan \& Gau, 2005) caused by functional illiteracy. As a result, they have the view that marketing strategies are ethically questionable or mistaken, since they assume that consumers have full knowledge. Providing consumer literacy involves consumer agency and the knowledge and capacity to manage consumer decisions, independently of social or situational issues in a "manner that satisfies consumer needs in the market" (Adkins \& Ozanne, 2005, p. 93). Mansfield and Pinto (2008) investigate cognitive handicaps and basic knowledge of credit cards, including the great potential to suffer economic, physical and psychological harm. Mason and Pavia (2014) suggest a relationship between vulnerability and the body, whether it is healthy or has some disease, of advanced age or has a deficiency, and this indicates fertile ground for issues related to the body as the fundamental conductor, which limits or does not limit the capacity to engage in market relationships.

Smith and Cooper-Martin (1997, p. 4) define vulnerable consumers as: "[...] those most susceptible to economic, physical or psychological harm, or as the result of economic transactions due to characteristics that limit their capacity to maximize their utility and well-being." These "consumers in situations of risk" due to personal deficiencies or personal circumstances, "[...] can be harmed by commercial practices or may be incapable of taking full part in market opportunities" (Pechmann et al., 2011 , p. 23). Initially concentrated on the poor, illiterate, racial minorities, immigrants or women, by the turn of the century these studies extended to the handicapped, youths, children, people homeless (because of natural disasters), lesbians, gays, bisexuals, and transgender individuals. The work of Visconti (2016) makes it possible to verify these new approaches. 
Frequently thinking about the antecedents of vulnerability requires questioning whether this is an individual issue or is appropriate for given groups of consumers, even though it is recognized as a consequence of "complex social relationships and processes" (Hilhorst \& Bankoff, 2004, p. 1). To Baker et al. (2005), even though there are some characteristics and factors that facilitate vulnerability, defining this based on groups is not the best path, as pointed out by Brenkert (1998), to whom only consumers who are typically subjected to some substantial level of harm are vulnerable (even though he clarifies that being "susceptible" to vulnerability does not necessarily signify being vulnerable). Berg (2015) and Woodliffe (2007) also question the idea that given groups are vulnerable arguing that not all can be considered equal by the market, given that some have more difficulties than others. Berg $(2015$, p. 284$)$ studies the elderly as potentially vulnerable consumers and states that despite some physical limitations, it seems to be less probable that, compared to others, they make unfortunate decisions at the moment of consumption.

Various studies address how age, race, sex, education and income can influence the consumer's capacity to understand and make decisions, pointing out demographic characteristics that can place them at a disadvantage (Hill, 2005). Shultz II and Holbrook (2009) use education and cultural capital and income to create a typology: economically vulnerable (do not have access to benefits), culturally vulnerable (do not have knowledge of benefits), doubly vulnerable (do not have access to benefits or knowledge of them) and the invulnerable (have access and knowledge). Unlike them, Adkins and Jae (2010) mention the importance of identifying more susceptible groups, understanding that, to some, vulnerability may be permanent - as argued by Commuri and Ekici (2008).

To Diniz, Pereira and Bellini (2014), vulnerability is related to issues of consumer fragility and can be situational or circumstantial, while not being directly linked to the economic-social level of individuals - such as youths addicted to the internet. In terms of youths, there are indications that this is a permanent vulnerability. Souza and Silva (2006) call attention to the vulnerability identified in youths due to marketing strategies, seen as having been "educated" and "conditioned" to aspects related to the consumer society, which has contributed to youths being investigated to determine whether they have become dependent and are now incapable of being demanding and critical.

Transitory states due to mourning or diseases are causes of CV (Hamilton, Dunnet \& Piacentini, 2015, p. 1) which can be aggravated. To Rittenburg and Lunde (2016, p. 198), even though merchants do not have (or have little) control over "individual characteristics or states", generally, "they have a level of influence over some external conditions" and, certainly, "have control over the context of consumption in which vulnerability is experienced." In this manner, some agents take advantage of consumers' lack of knowledge of the market, as well as transitory states which make them more fragile - such as mourning (Silva \& Barros, 2018).

\section{Ethical issues}

From this perspective ethical discussions about vulnerability are prevalent, and it even criticizes the role of marketing in increasing CV. Even though they can offer comfort and security to thousands of consumers, "[...] marketing professionals are frequently ridiculed, often with reason, for exploiting consumers in general and taking advantage of vulnerable consumers in particular" (Shultz II \& Holbrook, 2009, p. 124). Observe, in this sense, that vulnerability and opportunism, walk hand in hand, as has also been pointed out by Silva and Barros (2018).

In a complementary manner, Jones and Middleton (2007) state that consumers have not shown themselves to be capable of distinguishing whether their level of vulnerability is high or low in the face of marketing strategies. That is, the consumer cannot adequately evaluate whether company marketing strategies are ethical or not in terms of socio-environmental contributions and the damages that products can cause. Jones and Middleton (2007) emphasize that consumers can even want to consume products considered "correct", but often are not able to because they do not understand the "nature of the product".

There are also studies that emphasize the fact that a company's value is affected in a negative way by the adoption of practices considered to be unethical in relation to more vulnerable consumers (Tipton, Bharadwaj \& Robertson, 2009). Wolburg (2005) wonders whether, when the target is vulnerable and potentially harmful products are offered (e.g., predatory lending, cigarettes and alcohol), this relationship becomes incorrect. This vision is based on the assumption that CV is an externality to marketing activities, and therefore is not considered part of the market structure, which is debatable and is argued against by Nason (1989). 
Vulnerability can be a consequence of a lack of knowledge of companies and society about consumers, but it also can be done in bad faith (Silva, Abreu \& Mano, 2015), which has the potential for greater and greater harm "[...] like the introduction of Facebook, Twitter, and other means of segmenting consumers" (Rittenburg \& Lunde, 2016, p. 190), including psychological manipulations with increased credit, which leads to greater spending, above all people who are more susceptible to vulnerability (Harrison \& Massi, 2011).

To Smith and Cooper-Martin (1997), the greater preoccupation with ethical issues arises with harmful products which require that formulators of public policies think of potentially vulnerable groups to educate them about the harm that products can cause. Pechmann et al. (2011, p. 23) also argue in favor of the need for public policies for what they call "consumers in situations of risk" and, in the same way, Shultz II and Holbrook (2009, p. 124) state that "[...] we need to develop the existing framework in a way that inspires new ideas, appropriate policies and effective practices of intervention."

\section{Consumer vulnerability as a result of marketing systems}

In the third perspective, we find studies that identify that the market competes for vulnerable consumers, by the absence of, or errors in, legislation, and by the influence that it exercises on consumer agency, among other examples. Even though it is quite similar to the previous perspective, this perspective clearly relates the marketing system to vulnerability.

The fashion market, for example, is presented by Ertekin and Atik (2015) and Barros, Merabet and Gouveia (2015) as one of the causes of child sexualization, whether it consists of children portrayed in adult and sensual poses, or encouraging the consumption of products and services which are not appropriate for children and adolescents. Pechmann, Levine, Loughlin and Leslie (2005) demonstrate the vulnerability of adolescents in relation to the influence of advertising and promotion. Silva, Barros and Gouveia (2017) discuss the popularization of sport food supplement sales to children and youths. This shows there is a need for regulation, because the education of consumers has not been enough to protect them, due to their being unable to understand the technical details of the product. Silva and Barros (2018) identify in the mortuary market, errors and imperfections involving the retention of, and a lack of, information which causes CV.

As we have highlighted, frequently the efforts to understand vulnerability lie within the domain of micromarketing. Through this approach, the consequences due to market activities should not be considered externalities, but rather an integral part of these transactions. The consequences of these market transactions can affect different groups of society in distinct ways and this approach is useful to develop the public policies necessary to social well-being (Nason, 1989), which, among other issues, are related to CV. Shultz II and Holbrook (2009) also point to the negative results of the production, commercialization and consumption practices of products and services. To Layton and Grossbart (2006), for example, the evaluation of economic, physical, ecological, social and psychological risks of marketing systems has been of interest to public policies, because it involves, in some cases, ethical and moral issues.

The typologies of Baker and Mason (2012) and Baker et al. (2005) recognize the market's contribution to CV, but Hill (2005) notes that there are few studies about the market's structural characteristics and its relationship with demographic factors.

Consumer agency is a substantially debated aspect (e.g., Gould \& Semann, 2014; McKeage, Crosby \& Rittenburg, 2015). This is because as much as we can imagine that the consumer has power over his or her decision making, the market can have influence on the consumer's agency, mainly when part of the group has potential for vulnerability and/or stigmatization by society. McKeage et al. $(2015$, p. 71$)$ research a variety of gender identities including transgender and genderqueer, and affirm that "[...] the influence that the market exercises on consumer agency within this context has potentially significant consequences for this group of individuals." In this sense, many authors (e.g., Mirosa \& Wooliscroft, 2013; Silva \& Barros, 2018) understand that the consumer is not in control and that the marketing system contributes even if inadvertently - to CV.

The equilibrium between intervention and interference in marketing activities is important. Mittelstaedt, Duke and Mittelstaedt (2009) highlight the vulnerability that the marketing system imposes on the health system. Pearson and Liu-Thompkins (2012, p. 1) reflect that "[...] since the direct marketing to consumers of genetic tests has increased in popularity, there is a growing need to better understand the ethical and public policy implications of these products." In this way, there are four great 
tensions: "(1) vulnerability versus forces, (2) radical versus marginal changes, (3) directing versus not segmenting, and (4) encouraging knowledgeable versus naive consumers," understanding that what is most important is "[...] including consumers at risk as market participants and identifying directions for future research" (Pechmann et al., 2011, p. 23).

However, Rittenburg and Lunde (2016, p. 198) point out that "[...] public policy decisions walk a thin line between protecting consumers at risk of becoming vulnerable, and maintaining freedom of choice and access to market information and products." In this way, to the authors, the role of academics in micromarketing should be "[...] obtaining a clearer understanding of this phenomenon and finding viable solutions for its negative effects, without undervaluing individual rights" (Rittenburg \& Lunde, 2016, p. 200).

\section{FINAL CONSIDERATIONS}

Innovations - frequently seen as beneficial - can also impose challenges. Advances in the area of health, such as fertilization treatments and genetic research, offer potential problems, some of which have no precedents and can require public policies (Pearson \& Liu-Thompkins, 2012). In the same way, advances in nutrition, as is the case with food supplements, have already revealed themselves to be problematic in terms of their popularization even for children (Silva et al., 2017).

Whether instigated by a lack of public knowledge or bad faith on the part of organizations, research on vulnerability can provide supplementary material which broadens consumer protection beyond the legal point of view, which can be limited. It is believed that the study of vulnerability also should stimulate the development of appropriate public policies and the discussion of regulatory activities which protect all entities within the marketing system. The existence of the Consumer Defense Code (CDC) and other consumer protection bodies indicate concern, but are not sufficient by themselves, because marketing activities can affect other agents.

Some of the articles analyzed are dedicated to defining and contextualizing CV (e.g., Pavia \& Mason, 2014; Piacentini et al., 2014), pointing to the non-existence of a unanimous vision of this term. It may be observed, however, that most of the studies define it not as a property of given groups or environments, but as something contextual and not permanent. However, this does not mean that for some it cannot be permanent given the conditions that marginalize them or place them at a disadvantage, such as the homeless, gays, and illegal immigrants (Visconti, 2016). Vulnerable consumers and dominant groups may be engaged within the same context, but in unequal and asymmetric manners, which underlines the importance of investigating consumer well-being.

Box 2 presents the perspectives of the main contributions to this body of literature, following the example of Arnould and Thompson (2005). 
Box 2

Perspectives and their Contributions

\begin{tabular}{|c|c|c|}
\hline & Author(s) & Contributions \\
\hline \multirow{4}{*}{$\begin{array}{l}\text { Conditions which } \\
\text { lead to vulnerability }\end{array}$} & $\begin{array}{l}\text { Baker et al. } \\
\quad(2005)\end{array}$ & $\begin{array}{l}\text { Definition of } \mathrm{CV} \text { and the presentation of a model which considers factors } \\
\text { which increase the possibility of an occurrence of vulnerability, experiences } \\
\text { of vulnerability and consumer responses. }\end{array}$ \\
\hline & $\begin{array}{l}\text { Commuri and Ekici } \\
\text { (2008) }\end{array}$ & $\begin{array}{l}\text { Definition of CV as the sum of two components: a systemic component based } \\
\text { on class and a transitory component based on state. }\end{array}$ \\
\hline & $\begin{array}{l}\text { Shultz II and Holbrook } \\
\text { (2009) }\end{array}$ & $\begin{array}{l}\text { Creation of a CV typology: doubly vulnerable (do not have access to beneficial } \\
\text { means and do not have knowledge of benefits), economically vulnerable } \\
\text { (do not have access to benefits), culturally vulnerable (do not have knowledge of } \\
\text { benefits) and invulnerable (have access to benefits and knowledge of benefits). }\end{array}$ \\
\hline & $\begin{array}{l}\text { Baker and Mason } \\
\qquad(2012)\end{array}$ & $\begin{array}{l}\text { Creation of a conceptual model which makes it possible to analyze vulnerability, } \\
\text { considering pressures, disparate events, ideological tensions, state of vulnerability } \\
\text { and resilience, as well as the actions of various actors. }\end{array}$ \\
\hline Ethical issues & $\begin{array}{l}\text { Jones and Middleton } \\
\text { (2007); } \\
\text { Smith and Cooper-Martin } \\
\text { (1997) }\end{array}$ & $\begin{array}{l}\text { Preoccupation with issues related to ethics in marketing and market strategies, } \\
\text { mainly when dealing with vulnerable consumers. }\end{array}$ \\
\hline \multirow{4}{*}{$\begin{array}{l}\mathrm{CV} \text { as the result of } \\
\text { marketing systems }\end{array}$} & $\begin{array}{l}\text { Shultz II and Holbrook } \\
\text { (2009) }\end{array}$ & $\begin{array}{l}\text { Finding that production, commercialization and consumption practices of } \\
\text { products and services can produce direct and/or indirect negative results on } \\
\text { consumers and/or society in general. }\end{array}$ \\
\hline & $\begin{array}{l}\text { Mirosa and Wooliscroft } \\
\text { (2013) }\end{array}$ & $\begin{array}{l}\text { Identification that consumers are vulnerable to the forces of exploitation by } \\
\text { the main global neoliberal market actors. }\end{array}$ \\
\hline & $\begin{array}{l}\text { McKeage et al. } \\
\qquad(2015)\end{array}$ & $\begin{array}{l}\text { Finding that the market can facilitate or impede control and that the influence } \\
\text { of the market on consumer agency has consequences. }\end{array}$ \\
\hline & $\begin{array}{l}\text { Silva and Barros } \\
\qquad(2018)\end{array}$ & $\begin{array}{l}\text { Identification that market practices influence and deepen vulnerability and } \\
\text { that consumers do not have agency (they are passive). }\end{array}$ \\
\hline
\end{tabular}

Source: Elaborated by the authors based on the data from this study.

Our analysis reveals that CV studies have already formed an important theoretical body of work, which still requires attention. We propose, through this review, a definition of the concept of vulnerability which can orient potential empirical studies: vulnerability is a state of fragility of individuals when confronted with market practices, which may be manifested during different phases of the production, commercialization and consumption processes. This fragility can be presented by the consumer, as well as workers involved in the production and commercialization of the good, and/or indirectly by other individuals and by society in general, by virtue of the damages that marketing practices can cause to the natural, social and cultural environment. Experiences of vulnerability may be more probable and/or more severe in individuals and groups with some type of limitation.

Our proposition represents an advance in relation to previous studies in recognizing vulnerability throughout the marketing system and not just in the final consumer of the product. Marketing systems can be defined as "[...] networks of individuals, groups or entities directly or indirectly linked through participation in the process that creates, builds, transforms, and makes available tangible or intangible products in response to consumer demands" (Layton, 2007, p. 230). We consider the market's point of view through the idea of a marketing system to be important to understanding that vulnerability is much more probable and current than simply looking at the unethical practices of some companies. 
We understand that it is fundamental that Administration and more specifically Marketing and Consumption Studies be interested in protecting and benefitting consumers and society in general. Hunter-Jones, Baron and Warnaby (2014, p. 107) argue that "[...] the gap in research up until now has been a real attempt to differentiate the needs of those who experience temporary or permanent vulnerability" and, even though there has been progress, "[...] the fundamental commitment remains to protect consumers at risk and not label or marginalize consumer segments" (Rittenburg \& Lunde, 2016, p. 190). This is why this article is a call to action so that markets will be investigated in terms of the vulnerability of consumers, the workers involved in the production and commercialization of new offerings in the market, and the environment. 


\section{REFERENCES}

Adkins, N. R., \& Jae, H. (2010). Marketplace vulnerability of limited English proficient consumers: opportunities to increase knowledge in macromarketing. Journal of Macromarketing, 30(1), 93-104.

Adkins, N. R., \& Ozanne, J. L. (2005). The low literate consumer. Journal of Consumer Research, 32(1),93-105.

Arnould, E. J., \& Thompson, C. J. (2005). Consumer culture theory (CCT): twenty years of research. Journal of Consumer Research, 31(4), 868-882.

Bagozzi, R. P. (1977). Structural equation models in experimental research. Journal of Marketing Research, 14(2), 209-226.

Baker, S. M. (2009). Vulnerability and resilience in natural disasters: a marketing and public policy perspective. Journal of Public Policy \& Marketing, 28(1), 114-123.

Baker, S. M., Geiger-Oneto, S., \& Gentry, J. W. (2011). Potential vs. actual vulnerability in the marketplace. In Proceedings of 36 Annual Macromarketing Conference, Laramie, Wyoming. Retrieved from http://society.macromarketing.org/conference

Baker, S. M., Gentry, J. W., \& Rittenburg, T. L. (2005). Building understanding of the domain of consumer vulnerability. Journal of Macromarketing, 25(2), 128-139.

Baker, S. M., \& Mason, M. (2012). Toward a process theory of consumer vulnerability and resilience: Illuminating its transformative potential. In D. G. Mick (Ed.), Transformative consumer research for personal and collective well-being (pp. 571-592). New York, NY: Routledge.

Barros, D. F., Merabet, D. D. O. B., \& Gouveia, T. M. A. (2015). Público-alvo ou consumidor vulnerável? Histórico da legislação sobre a publicidade infantil em uma perspectiva de macromarketing. In Anais do 6 o Congresso Nacional de Administração e Contabilidade, Rio de Janeiro, RJ.

Berg, L. (2015). Consumer vulnerability: are older people more vulnerable as consumers than others? International Journal of Consumer Studies, 39(4), 284-293.

Bitencourt, J. O. D. S. (2004). O princípio da vulnerabilidade: fundamento da proteção jurídica do consumidor. Revista da EMERJ, 7(25), 248-265.

Boschi, M. R., Barros, D. F., \& Sauerbronn, J. F. R. (2016). A introdução da disciplina de marketing no Brasil: "uma linguagem comum que nos une". Farol-Revista de Estudos Organizacionais e Sociedade, 3(8), 888-956

Brenkert, G. G. (1998). Marketing and the vulnerable. Business Ethics Quarterly, 1(spe.), 7-20.

Caplovitz, D. (1963). Poor pay more: consumer practices of low-income families. New York, NY: Free Press.

Coda, R. C., \& Castro, G. H. C. D. (2019). Marketing business-tobusiness: análise da produção científica brasileira de 2008 a 2018. Revista de Administração de Empresas, 59(4), 258-270.

Commuri, S., \& Ekici, A. (2008). An enlargement of the notion of consumer vulnerability. Journal of Macromarketing, 28(2), 183-186.

Demo, G., Fogaça, N., \& Costa, A. C. (2018). Políticas e práticas de gestão de pessoas nas organizações: cenário da produção nacional de primeira linha e agenda de pesquisa. Cadernos EBAPE.BR, 16(2), 250-263.

Diniz, I. S. F. N., Pereira, R. D. C. D. F., \& Bellini, C. G. P. (2014). Limitações digitais em adolescentes: um estudo sob a perspectiva da teoria da vulnerabilidade do consumidor. In Anais do 6o Encontro de Marketing da Associação Nacional de Pós-Graduação e Pesquisa em Administração, Porto Alegre, RS.

Ertekin, Z. O., \& Atik, D. (2015). Aging of youth through fashion: influential dynamics and societal implications. In Proceedings of 40 음 Annual Macromarketing Conference, Laramie, Wyoming. Retrieved from http://society.macromarketing.org/conference/

Ferenhof, H. A., \& Fernandes, R. F. (2016). Desmistificando a revisão de literatura como base para redação científica: método SSF. Revista $A C B, 21(3), 550-563$.

Ferrari, A., \& Takey, D. G. (2014). O princípio da vulnerabilidade no código de defesa do consumidor. JICEX, 3(3), 1-7.

Gould, S., \& Semaan, R. W. (2014). Avoiding throwing out the baby with the bathwater: critically deconstructing contested positions on social and macromarketing in the health domain. Journal of Macromarketing, 34(4), 520-531.

Hackley, C. (2009). Parallel universes and disciplinary space: the bifurcation of managerialism and social science in marketing studies. Journal of Marketing Management, 25(7-8), 643-659.

Hamilton, K., Dunnett, S., \& Piacentini, M. (2015). Consumer vulnerability: Conditions, contexts and characteristics. London, UK: Routledge.

Harrison, P., \& Massi, M. (2011). Congratulations, you're pre-approved: the policy implications of credit limit upselling. In Proceedings of 36o Annual Macromarketing Conference, Laramie, Wyoming. Retrieved from http://society.macromarketing.org/conference/

Hemais, M. W., \& Faria, A. D. A. (2012). Um olhar sobre consumerismo que marketing pouco atenta (um tipo de miopia?). In Anais do 36응 Encontro Nacional da Associação Nacional de Pós-Graduação e Pesquisa em Administração, Rio de Janeiro, RJ.

Hilhorst, D., \& Bankoff, G. (2004). Introduction: mapping vulnerability. In G. Bankoff, G. Frerks, \& D. Hilhorst (Eds.), Mapping vulnerability: Disasters, Development and People. London, UK: Earthscan.

Hill, R. P. (2005). Special Issue on Vulnerable Consumers. Journal of Macromarketing, 2(2), 201.

Hunt, S. D. (1976). The nature and scope of marketing. Journal of Marketing, 40(3), 17-28.

Hunt, S. D., \& Burnett, J. J. (1982). The macromarketing/micromarketing dichotomy: a taxonomical model. Journal of Marketing, 46(3), 11-26.

Hunter-Jones, P., Baron, S., \& Warnaby, G. (2014). Exploring the Temporality of Consumer Vulnerability. In Proceedings of 39ㅇ Annual Macromarketing Conference, Laramie, Wyoming. Retrieved from http://society.macromarketing.org/conference/

Jones, J. L., \& Middleton, K. L. (2007). Ethical decision-making by consumers: the roles of product harm and consumer vulnerability. Journal of Business Ethics, 70(3), 247-264. 
Karpatkin, R. H. (1999). Toward a fair and just marketplace for all consumers: the responsibilities of marketing professionals. Journal of Public Policy \& Marketing, 18(1), 118-122.

Kuzma, E. L., Doliveira, S. L. D., \& Silva, A. Q. (2017). Competências para a sustentabilidade organizacional: uma revisão sistemática. Cadernos EBAPE.BR, 15(esp.), 428-444.

Layton, R. A. (2007). Marketing systems - a core macromarketing concept. Journal of Macromarketing, 27(3), 227-242.

Layton, R. A., \& Grossbart, S. (2006). Macromarketing: past, present, and possible future. Journal of Macromarketing, 26(2), 193-213.

Lei no 8.078, de 11 de setembro de 1990. (1990). Dispõe sobre a proteção do consumidor e dá outras providências. Retrieved from http://www.planalto.gov.br/ccivil_03/leis/L8078.htm

Lima, S. M. D. (2011). Vulnerabilidade e Hipossuficiência na sistemática do Código de Defesa do Consumidor. Revista do Centro Acadêmico Afonso Pena, 14(2), 241-259.

Macromarketing Conference. (2018). In Proceedings of 43으 Annual Macromarketing Conference, Laramie, Wyoming. Retrieved from http://society.macromarketing.org/conference/

Mansfield, P. M., \& Pinto, M. B. (2008). Consumer vulnerability and credit card knowledge among developmentally disabled citizens. Journal of Consumer Affairs, 42(3), 425-438.

Mason, M., \& Pavia, T. (2014). Health and consumer vulnerability: identity dissolution and resiliency behaviors. In J. Cotte, \& S. Wood (Eds.), NA - Advances in Consumer Research (v. 42, pp. 7-11). Duluth, $\mathrm{MN}$ : Association for Consumer Research.

McKeage, K. K., Crosby, E., \& Rittenburg, T. L. (2015). Gender identity and consumer vulnerability. In Proceedings of 40 o Annual Macromarketing Conference, Laramie, Wyoming. Retrieved from http://society.macromarketing.org/conference/

Miranda, C. M. C., \& Arruda, D. M. D. O. (2004). A evolução do pensamento de marketing: uma análise do corpo doutrinário acumulado no século XX. Revista Interdisciplinar de Marketing, 3(1), 40-57.

Mirosa, M., \& Wooliscroft, B. (2013). Experiencing vulnerability "everyday": Food choice. In Proceedings of 38ㅇ Annual Macromarketing Conference, Laramie, Wyoming. Retrieved from http://society.macromarketing.org/ assets/proceedings/2013-macromarketing-proceedings.pdf

Mittelstaedt, J. D., Duke, C. R., \& Mittelstaedt, R. A. (2009). Health care choices in the United States and the constrained consumer: a marketing systems perspective on access and assortment in health care. Journal of Public Policy \& Marketing, 28(1), 95-101.

Nason, R. W. (1989). The social consequences of marketing: macromarketing and public policy. Journal of Public Policy \& Marketing, $8(1), 242-251$.

Nason, R. W. (2011). Institutionalization of macromarketing. Journal of Historical Research in Marketing, 3(2), 261-268.

Oliveira, E. Q. D., Jr. (2010). O conceito de vulnerabilidade no direito penal. Retrieved from https://lfg.jusbrasil.com.br/noticias/2146510/o-conceitode-vulnerabilidade-no-direito-penal-eudes-quintino-de-oliveira-junior

Pavia, T. M., \& Mason, M. J. (2014). Vulnerability and physical, cognitive, and behavioral impairment: Model extensions and open questions. Journal of Macromarketing, 34(4), 471-485.
Pearson, Y. E., \& Liu-Thompkins, Y. (2012). Consuming direct-toconsumer genetic tests: the role of genetic literacy and knowledge calibration. Journal of Public Policy \& Marketing, 31(1), 42-572.

Pechmann, C. C., Levine, L., Loughlin, S., \& Leslie, F. (2005). Impulsive and self-conscious: adolescents vulnerability to advertising and promotion. Journal of Public Policy \& Marketing, 24(2), 202-221.

Pechmann, C. C., Moore, E. S., Andreasen, A. R., Connell, P. M., Freeman, D., Gardner, M. P. ... \& Soster, R. L. (2011). Navigating the central tensions in research on at-risk consumers: challenges and opportunities. Journal of Public Policy \& Marketing, 30(1), 23-30.

Piacentini, M., Dunnett, S., \& Hamilton, K. (2014). Patient, client, user, consumer? Issues involved with approaching vulnerability with consumer-focused terminology. In Proceedings of 38 Annual Macromarketing Conference, Laramie, Wyoming. Retrieved from http://society.macromarketing.org/conference/

Pinto, M. R., Batinga, G. L., Ássimos, B. M., \& Almeida, B. T. (2016). Transformative consumer research (TCR): reflexões, diretrizes e uma análise do campo no Brasil. Revista Interdisciplinar de Marketing, 6(2), 54-66.

Rittenburg, T. L., \& Lunde, M. B. (2016). Ethics in target market selection: A historical perspective. In Proceedings of 410 Annual Macromarketing Conference, Laramie, Wyoming. Retrieved from $\mathrm{http}: / /$ society.macromarketing.org/conference/

Santo, P. O. D. E., \& Hemais, M. W. (2017). Discriminação contra consumidores de baixa renda. Revista Pretexto, 18(1), 64-79.

Sauerbronn, J. F. R. (2013). Diga-me o que publicas e te direi quem és: perspectivas e resistências na publicação da produção de conhecimento em Marketing. Revista de Negócios, 18(1), 42-52.

Shapiro, S. J., Tadajewski, M., \& Shultz II, C. J. (2009). Interpreting macromarketing: the construction of a major macromarketing research collection. Journal of Macromarketing, 29(3), 325-334.

Sheth, J. N., \& Sisodia, R. S. A dangerous divergence: marketing and society. Journal of Public Policy \& Marketing, 24(1), 160-162.

Shultz II, C. J., \& Holbrook, M. B. (2009). The paradoxical relationships between marketing and vulnerability. Journal of Public Policy \& Marketing, 28(1), 124-127.

Silva, J. O. D., Abreu, N. R. D., \& Mano, R. F. (2015). Consumidores vulneráveis ou vulnerabilizados? Uma reflexão sobre a acessibilidade em meios hoteleiros na ótica das pessoas com deficiência física. In Anais do 29o Encontro Nacional da Associação Nacional de PósGraduação e Pesquisa em Administração, Belo Horizonte, MG.

Silva, R. O. D., \& Barros, D. F. (2018). A Vulnerabilidade do consumidor no mercado do morrer. In Anais do 8 Encontro de Marketing da Associação Nacional de Pós-Graduação e Pesquisa em Administração, Porto Alegre, RS.

Silva, R. O. D., Barros, D. F., \& Gouveia, T. M. D. O. A. (2017). Eu tenho a força! A popularização do consumo de suplementos alimentares e a vulnerabilidade do consumidor. Revista ADM.MADE, 21(1), 34-50.

Smith, N. C., \& Cooper-Martin, E. (1997). Ethics and target marketing: the role of product harm and consumer vulnerability. Journal of Marketing, 61(3), 1-20. 
A necessary discussion on consumer vulnerability: advances, gaps, and new perspectives
Rosana Oliveira da Silva | Denise Franca Barros

Tânia Maria de Oliveira Almeida Gouveia Daniel de Oliveira Barata Merabet
Souza, A. D. S., \& Silva, C. P. D. (2006). O consumo na vida de adolescentes de diferentes condições socioeconômicas: uma reflexão para o marketing no Brasil. Cadernos EBAPE.BR, 4(1), 1-18.

Tipton, M. M., Bharadwaj, S. G., \& Robertson, D. C. (2009). Regulatory exposure of deceptive marketing and its impact on firm value. Journal of Marketing, 73(6), 227-243.

Visconti, L. M. (2016). A conversational approach to consumer vulnerability: performativity, representations, and storytelling. Journal of Marketing Management, 32(3-4), 371-385.

Viswanathan, M., \& Gau, R. (2005). Functional illiteracy and nutritional education in the United States: a research-based approach to the development of nutritional education materials for functionally illiterate consumers. Journal of Macromarketing, 25(2), 187-201.

Wilkie, W. L., \& Moore, E. S. (2003). Scholarly research in marketing: exploring the " 4 eras" of thought development. Journal of Public Policy \& Marketing, 22(2), 116-146.

Wolburg, J. M. (2005). Drawing the line between targeting and patronizing: how "vulnerable" are the vulnerable?. Journal of Consumer Marketing, 22(5), 287-288.

Woodliffe, L. (2007). An empirical re-evaluation of consumer disadvantage. International Review of Retail, Distribution and Consumer Research, 17(1), 1-21.

Rosana Oliveira da Silva

ORCID: https://orcid.org/0000-0003-3971-5217

Ph.D. Student in Business Administration at Universidade do Grande Rio (UNIGRANRIO); Public Servant at the Fundação Oswaldo Cruz (FIOCRUZ).

E-mail: rooliveira35@outlook.com

Denise Franca Barros

ORCID: https://orcid.org/0000-0003-1640-6171

Ph.D. in Business Administration from the Fundação Getulio Vargas (FGV); Professor in the Graduate Program in Administration at Universidade do

Grande Rio (PPGA-UNIGRANRIO).E-mail: denise.barros@unigranrio.edu.br

Tânia Maria de Oliveira Almeida Gouveia

ORCID: https://orcid.org/0000-0002-8231-9714

Ph.D. in Business Administration from the Fundação Getulio Vargas (FGV); Professor at the Universidade do Estado do Rio de Janeiro (UERJ).

E-mail: almeida.tania@globo.com

Daniel de Oliveira Barata Merabet

ORCID: https://orcid.org/0000-0003-4582-3898

Ph.D. in Business Administration from the Universidade do Grande Rio (UNIGRANRIO). E-mail: danmerabet@gmail.com 